\title{
The first human settlement of Formentera during the Bronze Age
}

\author{
Pau Sureda ${ }^{1,2,3, *}$, Edgard Camarós ${ }^{4}$, Marián Cueto $^{4} \&$ Luis C. Teira $^{4}$
}

The ArqueoBarbaria archaeological project aims to characterise the economic strategies and environmental context of Formentera's first human settlers at two Bronze Age sites (Cap de Barbaria II and cave 127) using an interdisciplinary approach.

\section{Introduction}

The date of the first human settlement of the Balearic Islands in the Western Mediterranean is widely accepted to have been a late event, occurring sometime at the end of the third millennium cal BC (Cherry \& Leppard 2018). Initiated in 2012, the ArqueoBarbaria archaeological project aims to understand the Bronze Age settlement of the small island of Formentera through the excavation of two sites: Cap de Barbaria II (CBII) and cave 127 (Figure 1). The project's objectives are to characterise the economic strategies developed by the settlers, and to infer the environmental context within which they adapted to an extreme island environment.

\section{Cap de Barbaria II: the village}

CBII is an open-air village (Figure 1) of nine structures, three of which are naviforms (Figure 2). These are boat-shaped house structures built using a cyclopean masonry technique (e.g. Salvà \& Hernández-Gasch 2009), typical of domestic structures in the wider Balearic Bronze Age. Two different phases of construction have been identified at the site, and new radiocarbon dating attributes these to $1580-1531 \mathrm{cal} \mathrm{BC}$ (phase 1) and 997-927 cal BC (phase 2) (Sureda et al. 2017a). Abandonment of the village was probably related to the Phoenician colonisation of the island after the ninth century cal BC.

CBII was first excavated between 1979 and 1987 by the Archaeological Museum of Ibiza. Since 2012, a multidisciplinary project has conducted six seasons of fieldwork (2012-2017)

1 Instituto de Ciencias del Patrimonio (Incipit)—Consejo Superior de Investigaciones Cientificas (CSIC), Avenida de Vigo s/n., 15705 Santiago de Compostela, Spain

2 McDonald Institute for Archaeological Research, University of Cambridge, Downing Street, Cambridge CB2 3ER, $U K$

3 Homerton College, University of Cambridge, Hills Road, Cambridge CB2 8PH, UK

4 Instituto Internacional de Investigaciones Prehistóricas de Cantabria-IIIPC, Universidad de Cantabria, Avenida de los Castros 52, Edificio Interfacultativo, 39005 Santander, Spain

* Author for correspondence (Email: pau.sureda@incipit.csic.es)

(c) Antiquity Publications Ltd, 2018

ANTIQUITY 92 366, e4 (2018): 1-7

https://doi.org/10.15184/aqy.2018.253 


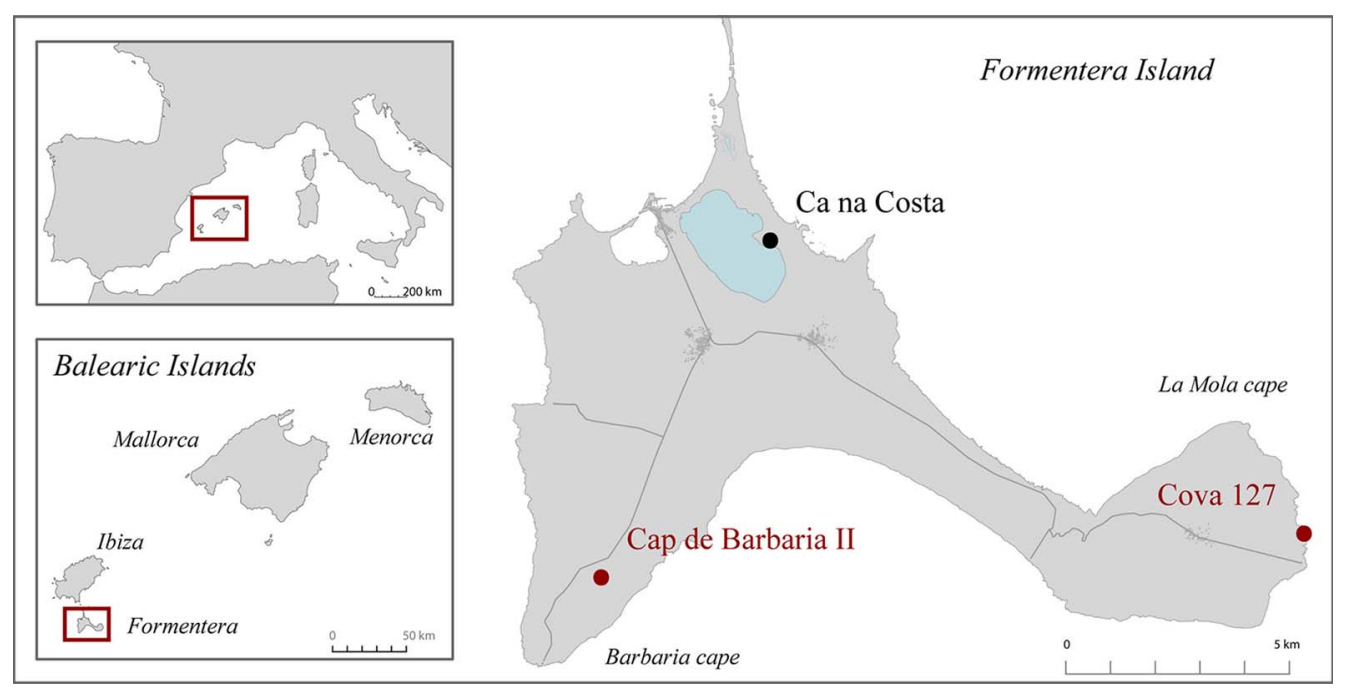

Figure 1. Location of Cap de Barbaria II and cave 127.

focused on naviforms 7-9 (Figure 3) and outside areas. Excavation of the naviforms has revealed a number of internal features: paved floors, benches, storage structures and hearths. Material culture is also abundant, including metal and flint artefacts, grinding stones, pottery, marine shells, animal bones, charcoal and seed remains, representative of both domestic and production activities (Figure 4). These materials have been subject to a variety of analyses: lithic studies, archaeometallurgical analysis, zooarchaeological and archaeobotanical approaches (including palynological, anthracological, starch grain and macrobotanical remains analysis), and petrological studies of the pottery (Sureda et al. 2017b).

\section{Cave 127: the funerary context}

Cave 127 (Figure 5) is a natural cave used for prehistoric burial. Since its discovery in 2014, archaeological remains relating to two buried individuals and their associated funerary goods have been recovered. These are contemporaneous with the Ca na Costa dolmen (the other known funerary context of the island) and with the oldest phase of CBII. A range of analyses on the material from cave 127 is currently ongoing, including radiocarbon dating, nitrogen and oxygen isotope analyses, palaeopathology and DNA.

\section{Preliminary results and future perspectives}

Island archaeology has long theorised about the mechanisms of colonisation, from initial discovery through to definitive settlement. Recent approaches (e.g. Ramis 2014) emphasise that island colonisations are closely related to social and technological conditions, and also to the 


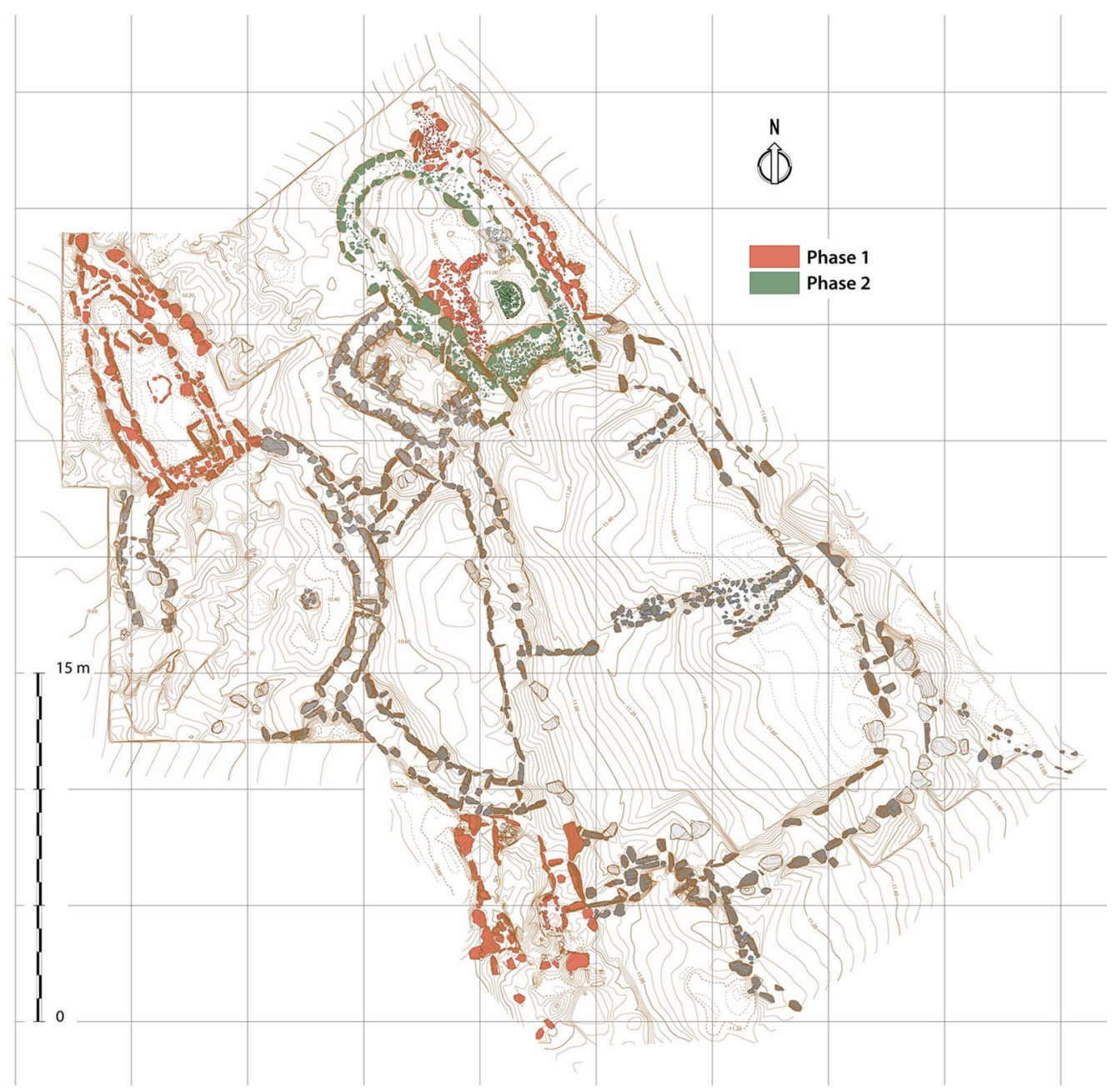

Figure 2. Plan of Cap de Barbaria II with the location of the excavation area.

local environmental resources available. Our project proposes three key questions: 1) how did the population cope with the scarcity of natural resources (metallic ores, flint, pastures or arable land)?; 2) did they overcome these limitations through the development of new economic strategies and/or by establishing maritime exchange?; and 3) did the settlers remain isolated throughout the Bronze Age?

These questions are essential for understanding how these first settlers exploited local and/ or exogenous resources to establish the first successful communities and how they guaranteed their subsistence. This approach aims to identify the presence or absence of insular particularities, and to assess the degree to which island populations were integrated into regional or long-distance exchange networks. 
Pau Sureda et al.
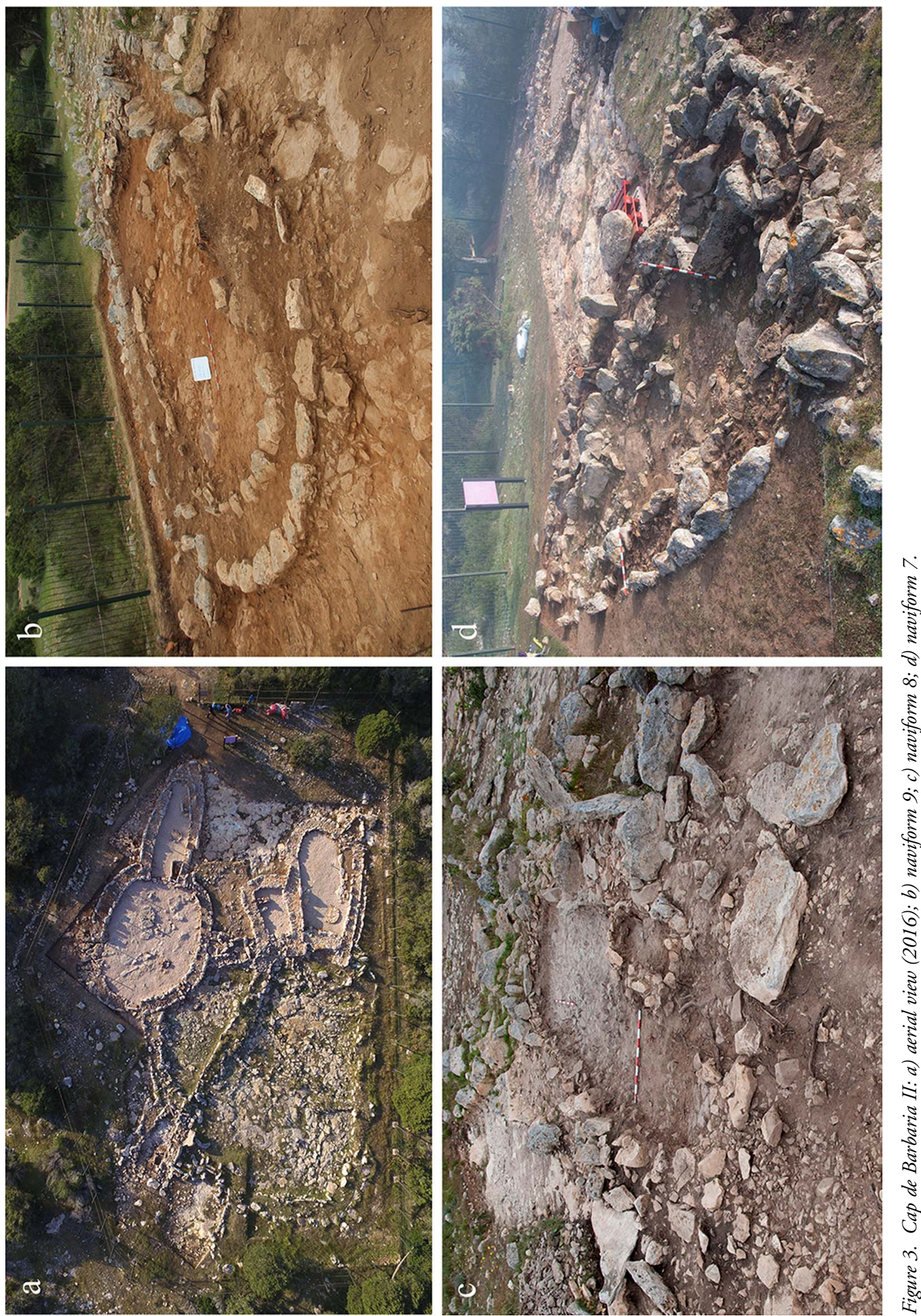

(C) Antiquity Publications Ltd, 2018 


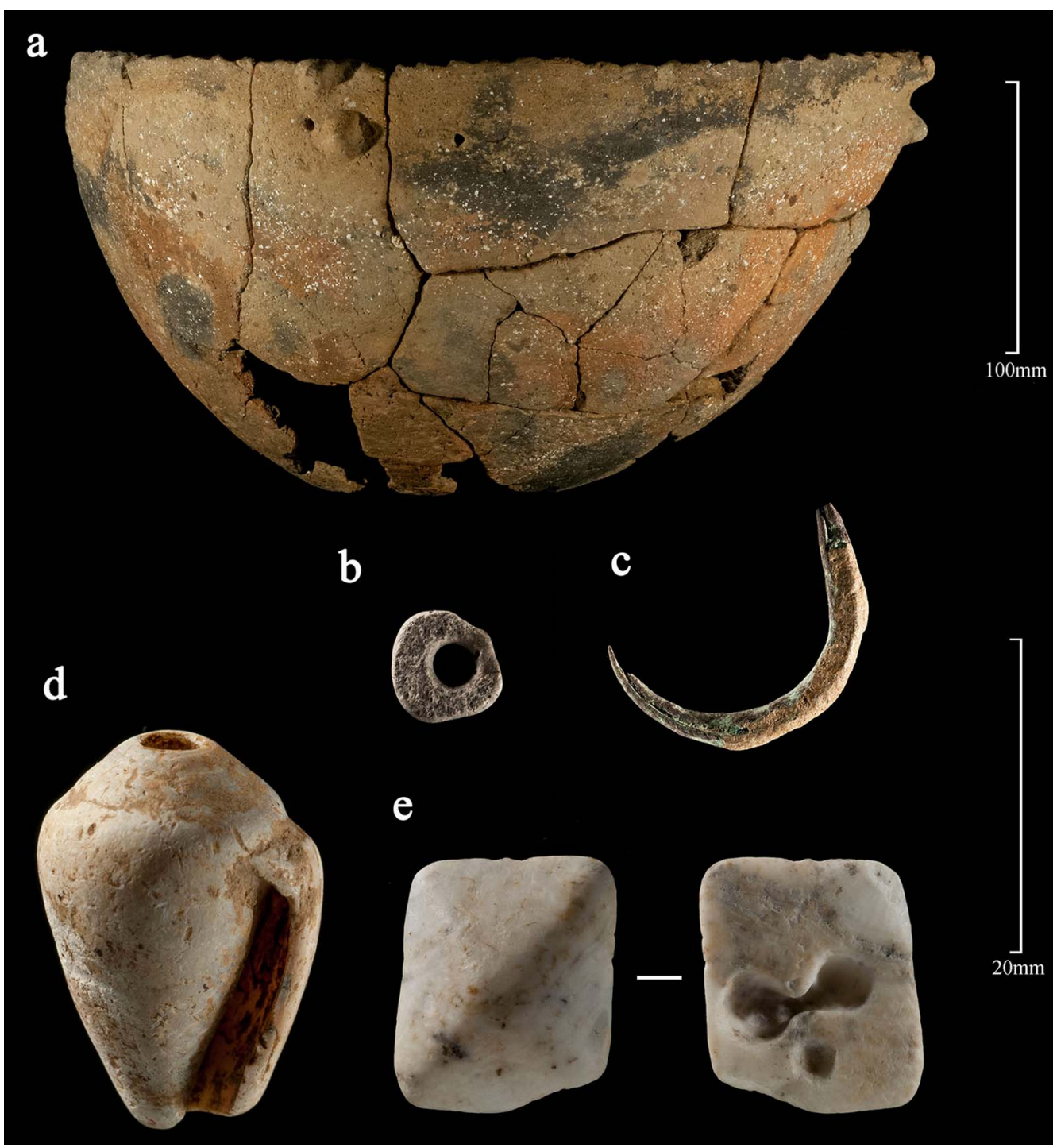

Figure 4. Selected materials: a) pottery sherd; b) limestone bead; c) copper hook; d) shell pendant; e) limestone button.

Our results suggest that the strategies developed in Formentera required specific adaptation of behaviours in comparison to other Balearic cases (Sureda et al. 2017b). Such adaptation required modification of the island's environment through the introduction of new species for optimal subsistence (e.g. caprines, millets) and intensive exploitation and diversification concerning the use of local resources (e.g. marine resources, limestone). Exogenous materials (e.g. copper-based metals, flint) have also been identified and are important for the evaluation of isolation $v$ s interaction. In sum, the results of our work on Formentera challenge 
Pau Sureda et al.
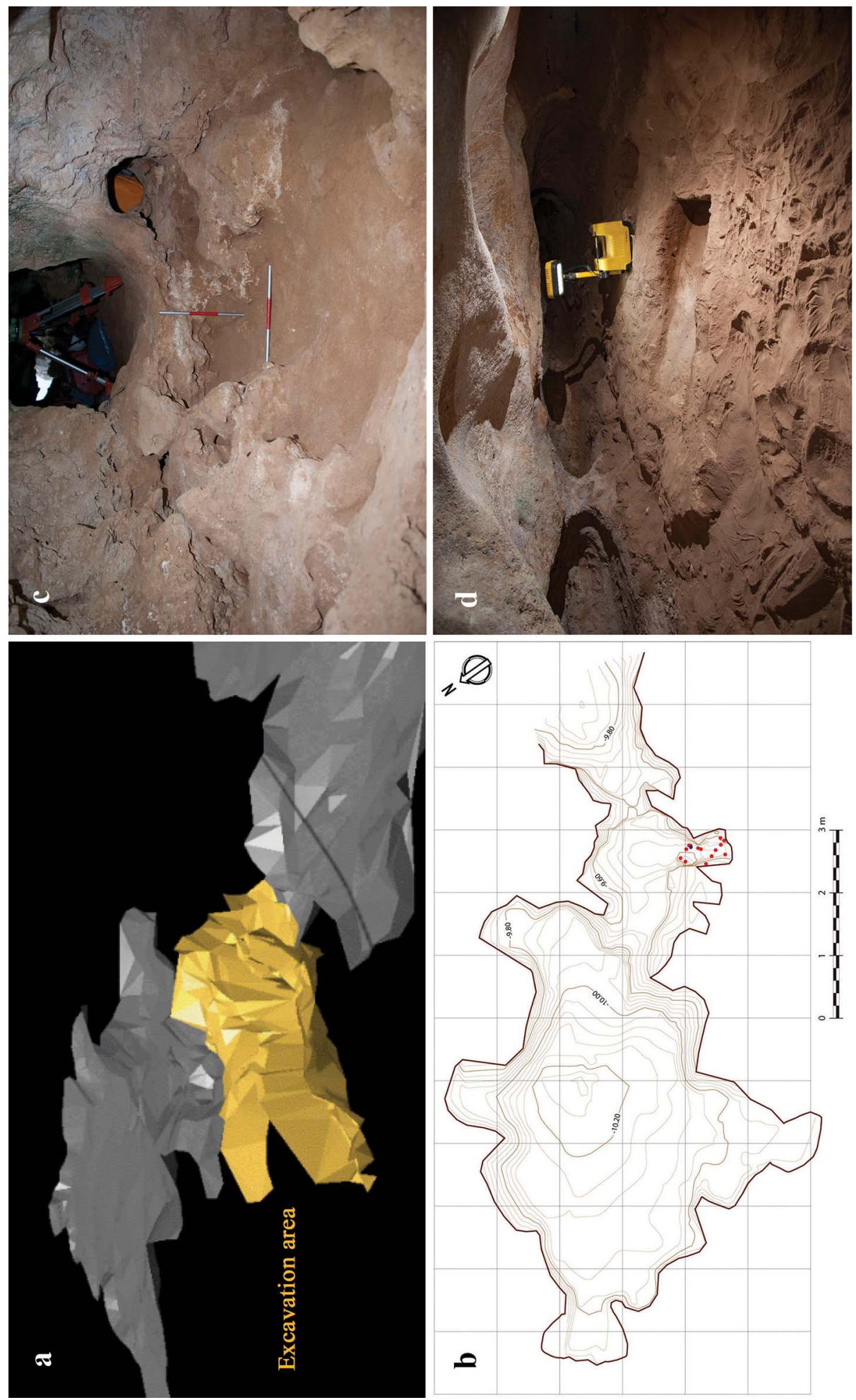

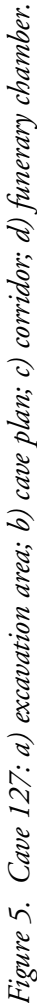

(C) Antiquity Publications Ltd, 2018 
ideas about the first human settlement of the Balearics, especially according to its specific subsistence strategies; future research will contribute to a better understanding of the wider Mediterranean Bronze Age.

\section{Acknowledgements}

The project is owned and managed by Incipit-CSIC and IIIPC/UC, and is also supported by the Consell Insular de Formentera.

\section{References}

Cherry, J.F. \& T.P. Leppard. 2018. The Balearic paradox: why were the islands colonized so late? Pyrenae 49: 49-70.

Ramis, D. 2014. Early island exploitations: productive and subsistence strategies on the prehistoric Balearic Islands, in A.B. Knapp \& P. Van Dommelen (ed.) The Cambridge prehistory of the Bronze and Iron Age Mediterranean: 40-56. New York: Cambridge University Press. https://doi.org/10.1017/CHO9781139028387.006

Salvì, B. \& J. Hernández-Gasch. 2009. Los espacios domésticos en las Islas Baleares durante las Edades del Bronce y del Hierro. De la sociedad Naviforme a la Talayótica, in M.C. Belarte (ed.) Actes de la IV Reunió internacional d'Arqueologia de Calafell (2007), Calafell: 299-322. Universitat de Barcelona: ArqueoMediterrània Collection.
Sureda, P., E. Camarós, M. Cueto, L.C. Teira, F.J. Aceituno, D. Albero,

E. Álvarez-Fernández, M. Bofill,

I. López-Dóriga, D. Marín, A. Masclans, L. Picornell, J. Revelles \& F. Burjachs. 2017a. Surviving on the isle of Formentera (Balearic Islands): adaptation of economic behaviour by Bronze Age first settlers to an extreme insular environment. Journal of Archaeological Science: Reports 12: 860-75. https://doi.org/10.1016/j.jasrep.2016.08.016

Sureda, P., E. Camarós, M. Cueto, L.C. Teira, E. Állvarez-Fernández \& I. López-Dóriga. 2017b. El poblado naviforme de Cap de Barbaria II (Formentera, Islas Baleares). Nuevos datos sobre su cronología y secuencia de ocupación. Trabajos de Prehistoria 74: 319-34.

https://doi.org/10.3989/tp.2017.12197 